\title{
ENRIQUE LIHN: \\ "Y LA AUSENCIA SE HIZO VERBO"
}

POR

\section{Christine Legault}

La presencia del intertexto manierista en la poesía de Lihn se radicaliza, sin duda alguna, a partir de La musiquilla de las pobres esferas (1969), obra que marca un viraje, si no una ruptura, en el lenguaje poético y en el registro temático del autor. Al mismo tiempo que éste vuelve a escribir versos de fisonomía más tradicional (cuartetos), desarrolla al extremo los temas de la soledad ("Seis soledades") y de la marginalidad del poeta, tanto en el amor como en su oficio de escribiente. Dichas características se intensifican hasta contagiar más seriamente el estrato formal de París, situación irregular (1977), colección que Lihn mismo percibe como su "mejor texto poético" $(1978-79,13)$; allí, "Ciertos sonetos" establecen un puente visible con la tradición sonetista del Siglo de Oro español, trátese de Herrera, de Góngora o de Quevedo. En Al bello aparecer de este lucero (1983), hallamos un tercer punto de anclaje para nuestro estudio, ya que el poemario representa, en nuestra opinión, la epifanía de la trayectoria poética iniciada con La musiquilla de las pobres esferas, o sea el dialogismo cultural y verbal llegados a su paroxismo.

Tanto en sus conversaciones con Pedro Lastra (1980) como en su "Curriculum" (197879), Lihn aborda varias veces el problema de la intertextualidad, que aprehende más como un antídoto contra la "fosilización del lenguaje poético" que como un verdadero "repensar" (Lastra 1980, 73), y reconoce la afinidad cultural que existe entre él y el Siglo de Oro español: se trata de “... una suerte de repetición en lo cultural, por parte de Hispanoamérica, del destino del siglo de oro español ... una necesaria combinación de escepticismo y esperanza" (Lastra 1980, 52). Quizás el rasgo poético que le aproxime más al manierismo ibérico sea su exigencia formal, la que le hace exclamar: "My current poetry ... must appear to Nicanor Parra ... as product of a pretentious baroque rhetoric, the counter position to the values of popular poetry to which he susbcribes in his own work ... " (Lihn 1978-79, 10).

Dicha exigencia llega a ser, en efecto, una constante retórica por la que el discurso se halla sometido a una compleja alquimia verbal. Así se engendra un estilo particularmente denso, recargado en sus tropos y sus figuras. En un estilo marcadamente gongorino, proliferan elipsis, volutas verbales, oxímora e hipérbatos, es decir procedimientos de condensación, de fragmentarización y de desplazamiento. Como para Góngora y Belli, el protagonista esencial de la obra es el lenguaje, ${ }^{1}$ un lenguaje invalidado, que se ha vuelto

\footnotetext{
${ }^{1}$ El protagonismo del lenguaje como recurso esencial de la poesía hispanoamericana actual ha sido ampliamente subrayado por J. R. Padrón, Antología de la poesía hispanoamericana (1984) 42.
} 
inadecuado para expresar la experiencia, y empuja al sujeto poético a emprender un viaje lingüístico exploratorio, con la meta de conjurar la ratio difficilis con el que ha de enfrentarse. La Palabra llega a destronar al hablante peregrino, exiliado o extranjero paradigmático, cuya identidad nunca está revelada ni en Góngora, ni en Belli, ni tampoco en Lihn. Las tres escrituras se alejan del lenguaje referencial, denotativo - por ilusorio que sea éstepara volverse hacia un sistema de significación esencialmente connotativo y dialógico. Se establece una cadena de significación metonímica, sincrónicamente —en el seno de la obra total del autor y de sus coetáneos-y diacrónicamente - mediante la realización de un dialogismo dinámico con los discursos anteriores. En los tres casos, puede notarse un alejamiento del modo de comunicación "ordinario" y, con esa sobrecarga de energía significante, una constante solicitación mental. Como Góngora, Lihn ve en la forma del soneto un modo de satisfacer la exigencia intelectual, y en consecuencia, un instrumento metalingüístico que le permite enjuiciar el mecanismo verbal en toda su inanidad y su dimensión represiva:

... en el uso de formas tan arcaicas y exigentes se espera del sonetista la aplicación de un jugador de ajedrez .... Al adoptar las [reglas] del soneto ... el lenguaje reconoce y releva su carácter de cosa hechiza, artificial, prefabricada ... el operar desde el lenguaje fosilizado es también la manipulación que efectúa la poesía del absurdo (Lastra 1980, 68-69). [El soneto es la] forma carcelaria en la cual se encarna el opresor de la que el oprimido se libera mostrándolo en su dimensión opresiva y, a nivel del lenguaje, en la suma de las infracciones que el locutor le impone a la forma del soneto (Lastra 1980, 70).

Al cotejar el entorno vital de los autores investigados en este estudio, sorprenderán al lector algunas turbadoras afinidades circunstanciales entre Góngora y Lihn, afinidades que quizás sirvan para aclarecer - aunque, lo subrayamos, de modo conjetural— otras afinidades de abolengo retórico-literario.

Los dos, cuya formación intelectual se desarrolla en un ambiente familiar desahogado y cultivado, tienen que padecer muy jóvenes un programa de "enlistamiento" religioso enérgicamente llevado a cabo por sus mayores. Góngora es pronto destinado a la carrera sacerdotal por un tío poseedor de beneficios eclesiásticos, mientras Lihn se ve acosado por las convicciones teológicas de su abuela, con sus inevitables "lecciones en misticismo racional" (Lihn 1978-79, 7):

... my maternal grandmother ... a subtle intelligence formed and deformed by the nineteenth century. Musician and trilingual reader, a natural theologian, intuitive, and blind ... hoped that one of her sons or I, qualitatively her only grandson (and there were many of us), rather than an artist, would be a practitioner of the art of sanctity. The modern world -obviously different from the one sho had known - was in need of redemption through the example of a new Saint Francis (Lihn 1978-79, 7).

Quizás de esta misma opresión espiritual nacieron ciertas veleidades de gandulería intelectual manifiestas en ambos hombres. En su introducción a los Sonetos completos de Góngora, Biruté Ciplijauskaité recuerda los propósitos de José Pellicer, el primer biógrafo de don Luis, quien nos da un retrato del joven cordobés bien distinto del que la tradición literaria 
quiere recordar. En vez de un personaje adusto y amargo, se nos ofrece la imagen de un joven calavera, alegre y travieso, algo tahúr, aficionado al teatro, a la música, a los toros, y de ingeniosa disposición para versificar $(1982,14)$. Tal picardía no deja de recordar lo de Lihn, estudiante en la Escuela de Bellas Artes, hecho un vago y un bohemio por los barrios estudiantiles de Santiago, el Lihn del "Pequeño Montparnasse", también dotado de una particular elocuencia literaria: "I had a certain facility with the written word. I was ignorant and eloquent ... (1978-79, 8). Más tarde, y en eso también se parece a Góngora, conoce períodos de escasez económica y queda reducido a explotar sus talentos literarios con lo que él mismo llama unos "sideline jobs", es decir unos trabajos suplementarios encargados $(1978-79,12)$.

Del mismo modo que en la obra del poeta cordobés se manifiesta antes que nada un hombre arraigado en las contingencias vitales de un desdorado Siglo de Oro, en la del poeta chileno late el pulso inquieto de una realidad social e histórica desasosegada. Lihn nos comunica en efecto la imagen de un mundo aleatorio, en que las formas de cognición han sido deslegitimizadas; su palabra doliente se hace paradigmática de todo el discurso humano occidental para el que se abre la ayermada era de la "represión cognoscitiva" (Fox Keller 1985, 139-49). El discurso lihniano, como el gongorino, se organiza alrededor de tres ejes esenciales: la solitaria peregrinación de vida, el desamor y la reflexión sobre el lenguaje.

Peregrino es como se aprehende Lihn cuando evoca su estadía en París: "when in 1965 I finally met up again with Alejandro Jodorowsky in Paris, I was a modest pilgrim dazzled by the City of Lights" $(1978-79,12)$; peregrino también es el poeta "de paso", y el extranjero de Paris, situación irregular; peregrino, en fin, el hablante de Estación de los Desamparados, el de Al bello aparecer de este lucero, y el de Pena de extrañamiento. El viaje real -a Francia, al Perú-y el exilio físico, la "peregrinación solitaria" $(P P 3)$, no tardan en cobrar dimensiones obviamente metafóricas en toda la obra poética: “... para siempre, estoy de paso / como la muerte misma: poeta y extranjero" ( $P P$ 9). Su odisea, entonces, no deja de ser un simulacro homérico, si bien desprovisto de punto de anclaje fijo al cual volver:

Ah soledad para la cual no hay freno ni otro camino que el que a ti me devuelve

El sonido del mar a una cierta distancia tenga por línea de rompiente esta voz y yo seré su lamentable Ulises ansioso de no importa qué sirena.

$(M 54)^{2}$

Y se resume a un periplo sin fin ni meta, cuyo rumbo parece tan sólo imantado hacia la soledad magnética del páramo:

error y horror de un viaje a cuyo término no llego (PSI 36)

\footnotetext{
${ }^{2}$ En el poema "Messaline", también evoca la absurdidad de algunas escenas de la Ilíada y de la Odisea (PSI 43).
} 
Piensa tú, toda esta gente, cualquier cantidad de millones que nunca supieron nada de tu existencia .... a pesar de

el esfuerzo inaudito de haber llegado hasta ellos arrastrando

el rídiculo maletín y el abrigo pasado de moda y los zapatos empapados por la lluvia torrencial de Paris (PSI 44)

Así, el hablante, "náufrago en la tierra" ( $A L B$ 62), llega a declinar la palabra "soledad" en todas sus modalidades temporales y circunstanciales. El poema "Seis soledades", en particular, evidencia la estrecha relación establecida entre peregrinación y soledad, mediante la hinchazón hiperbólica siguiente:

La soledad sin pausa de la que otros beben a la hora del cocktail no es mi vaso es mi tumba, me la llevo a los labios, braceo en ella hasta perderme de vista entre su oleaje mórbido.

La soledad no es mi canario es mi monstruo como si cohabitara con un asilo de locos.

(M57)

Su soledad es total, invasora, y se apodera totalmente de su persona:

¿Quiénes me habitan ya? Mis soledades con algo de enfermeros y de enfermos en una antigua casa de salud -rutina de unos y otros en que se amargan los años-

$(M 62)$

No se limita este estrago tan sólo a su persona, sino que contagia todo su entorno. Aquí, Lihn no trata de escapar del ámbito urbano corrompido mediante la creación de un lugar utópico ameno, como lo hacen Góngora y Belli. Al contrario, insiste en describirlo como la escena centrífuga de las desgracias y del desamparo humano, como un no lugar donde se encuentran y desencuentran los individuos en un vaivén perpetuo y vertiginoso, donde el hormigueo sólo significa abandono e indiferencia. Así es París, lugar en que cada cual se halla, por esta razón, en "situación irregular", así Manhattan, así Lima, "estación de los Desamparados", y así la ciudad mítica que sirve de trasfondo a la colección Pena de extrañamiento, mosaico también de desampararados, donde un ciego, una prostituta, una guitarrista, un travestista, unos agonizantes y convalecientes aúnan todos sus soledades respectivas. Ciudad y soledad llegan a ser, para el poeta, una suerte de fatalidad binaria y la concreción alienadora de un "univers robotisé, aseptisé et vide" (PSI 35). 
Esta dolorosa aflicción de transitoriedad viene a ser complicada, además, por la agudización, en el hablante, de un sentir marginal y enajenado, manifiesto primero en la insistencia pleonástica en su extranjerismo. Ya exiliado $(P P)$, ya "meteco" (PSI 71), ya "vagabundo" (PSI 87) o náufrago errando "entre plásticos restos de un naufragio" (PSI 93), siempre está destinado a la exclusión y al desencuentro, a la participación "por exclusión, entre paréntesis" (PSI 66) como los gitanos de Poesía de paso:

... forzados

a un nuevo exilio por los caminos de Provenza

bajo ese sol del viento que se ríe a mandíbula

batiente del verano y sus pequeños negocios

(PP 84)

Últimamente, está destinado al desamor y a la incomunicación —encarnados al principio de la trayectoria poética por Nathalie:

Desconocidos que se hacen reconocer
sin aportar nada a ese reconocimiento
como no sean las señales del mismo.
El ritual vacío de un reencuentro que antes
bien es
el encuentro con una persona doblemente
$\quad$ desconocida
en la medida en que para nada para nada
nos obliga a reconocerla
antes de haberla conocido.

(PSI 65)

Su "pasión de la derrota" ( $M 49$ ) le hace pregonar incluso: "El mensajero de la nada soy" $(A L B 36)$, le hace lamentar su "aspecto de empleado público de una provincia de Ninguna Parte" (PSI 67), y:

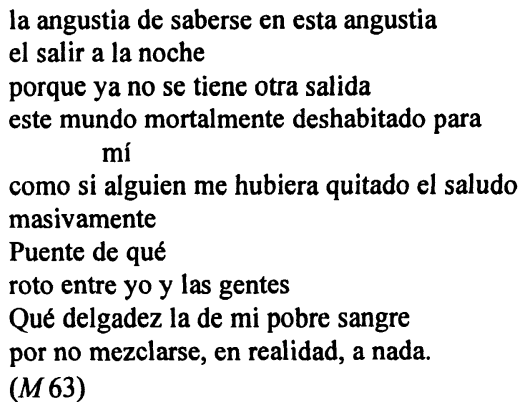

Llevado al paroxismo de aquella angustia, el hablante lihniano se siente irremediablemente desamparado y abandonado: 
Nadie puede anidar en una fosa $y$ en ese nido de sepulturero me abandonó, mientras dormía, Febo como el lector a las historias ciegas como el tapiz a los dibujos muertos como Teseo a Ariadna en una isla ( $A L B$ 43)

Como el peregrino de Góngora, el de Lihn cierra sobre sí el círculo de su propio soledad: "At the end, the pilgrim is exactly where he began: alone, incomplete, lost" (Beverley 1980, 84).

La experiencia, durante la larga jornada, de exclusión y de privación -desencuentro, desamor, silencio y ausencia - engendra un modo de escritura esencialmente fragmentado: la obra entera de Lihn es en ese respecto un diario de viaje sin principio ni fin, ni coherencia cronológica u objetiva, una metanarración, es decir, un corpus narrativo que, sin ser propiamente dicho "narración", funciona sin embargo como tal.

La fragmentación discursiva se manifiesta, en el poeta chileno, a tres niveles: primero, en el campo morfo-sintáctico (alteraciones rítmicas, proliferación de guiones superfluos, incongruencias, metáforas, metonimias, etc.) ${ }^{3}$ segundo, en el campo semántico (fractura de la coherencia textual mediante la multiplicación de rápidos cambios de enfoque, la confusión en las voces poéticas, los bruscos desplazamientos en el tiempo y en el espacio, las súbitas interrupciones, etc.), y tercero, en el dominio pragmático (necesidad, para el lector, de recontextualizar - sin garantía - un texto descontextualizado). ${ }^{4}$

Nótese que el fragmento no sólo significa "ruptura", sino también expresión nostálgica de una entereza perdida y echada de menos. Según confirman los diccionarios, un fragmento es, en el sentido propio, un pedazo separado de un todo por fractura y, en sentido figurado, es sea un trozo de texto conservado de una obra - un todo- perdido, sea un trozo cuidadosamente seleccionado, revelando así simultáneamente la huella de una unidad original, de una integridad perdida, y lo ausencia actualizada de un conjunto anhelado. Por eso, puede interpretarse el tema del viaje, tan ubicuo para Lihn, como el elemento deseante y nostálgico que intenta enlazar las muchas soledades desparramadas por las páginas con el sujeto disuelto en los versos: “... el viaje es un cambio de escenario que corrobora la persistencia del sujeto que viaja”, nos dice (Lastra 1980, 55):

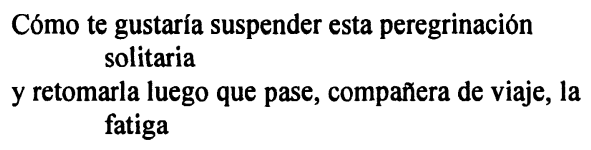

\footnotetext{
${ }^{3}$ No desarrollaremos más este punto aquí, ya que planeamos explorarlo en un trabajo ad hoc.

${ }^{4} \mathrm{~A}$ diferencia de lo que ocurre en la comunicación "ordinaria" entre el productor y el receptor, la relación entre el autor y el lector puede definirse más bien como metacomunicación: queda disrumpida, dejando que éste afronte sólo un parámetro particularmente desorientador de perturbación, por estar obligado a interpretar un texto descontextualizado (es decir, al nivel extensional, cuyas condiciones de producción se ignoran, y el nivel intensional, que está aislado del resto del corpus textual) para recontextualizarlo en un proceso semiótico.
} 
del extranjero para el cual todo se mezcla a ella,

...

Estabas advertido; había que viajar en compañía, pero en cambio viniste del otro lado del mundo

para mirar tu soledad a la cara (PP 3-4)

El anti-logos lihniano, esa atomización de la unidad orgánica de la experiencia y del discurso llega a perfilarse más bien como síntoma de la obsesión por ceñirse a un todo y alcanzar la Unicidad.

El recurso a la intertextualidad es, en este sentido, un procedimiento esencialmente fragmentario, que sigue el mismo paradigma de atomización/destrucción y de remiendo/ recomposición. Lihn reconoce la presencia de un elemento traumático y conflictivo en el uso que hace de la palabra ajena: "... although [my poetry] may integrate linguistic elements of the most diverse origins, signs of a traumatic relation with Literature prevail" $(1978-79,9)$. En otra ocasión, afirma, con respecto a la tradición literaria europea:

La Europa que [el poeta] reconoce se funda en un terreno movedizo e inconexo, es una informe "herencia cultural"; radica en lecturas desordenadas y heterogéneas, en recuerdos visuales, en lo que podríamos llamar una tradición de "alienación cultural" .... El éxodo hacia Europa parece pues un proceso de fototropismo, o casi. Quienes permanecemos en Hispanoamérica lo hacemos parcialmente en el exilio interior, y el lugar de ese exilio es Europa (Lastra 1980, 50-51).

París, situación irregular es sin ninguna duda el primer texto poético de Lihn que exhibe tan abiertamiente ese prurito citacional. Allí, la intertextuaildad se da en su forma más exagerada y alcanza un grado extremo de dispersión. Carmen Foxley, en su excelente prólogo, inventaría todas las modalidades de polilogismo presentes en el libro:

Entre esas escrituras se pueden señalar las citas extraídas de periódicos parisinos, los títulos de obras pictóricas, esquemas de las "Correspondencias" del Metropolitano, citas de escritores y críticos de arte, inscripciones en monumentos. También, formas del código de comunicación social: dedicatorias, despedidas, testamentos, instrucciones para el usuario. Formas del código de comunicación estético-literario: las frases antes señaladas, más algunas estrofas tradicionales. Formas de escritura propias de la crítica pictórica, o de lo descripción científica. A todas ellas se agregan los signos gráficos, las llaves, ideogramas y palabras invertidas (Foxley 1977, 22).

Como vemos, la retórica lihniana se aplica en recoger no sólo una tradición propiamente literaria sino también el conjunto cultural que configura a ésta en sus manifestaciones más diversas: arte popular, música, medios masivos de comunicación, pintura, graffiti, etc. ${ }^{5}$ Aun cuando evoca textos particulares, se trata más del espíritu que de su letra. Si Lihn no

${ }^{5}$ Numerosas son, además, las inserciones de palabras extranjeras en PSI, tales el ya citado epígrafe, y los vocablos siguientes: "N'importe où" (54), "Clôture électrique" (62), "garçon" (67), "”inter nos" (68), por no citar más que algunos ejemplos. Abundan también los galicismos, como "tener la tupé" (70) por "atreverse" (en francés: "avoir du toupet"). 
vacila en reconocer varias imprecisiones e incorrecciones (Lastra 1980,55), es porque está convencido de que lo único pertinente en la escritura citacional es el enjuiciamiento realizado, es decir, la dimensión metalingüística así alcanzada: tal escritura es una reflexión acerca de cómo y qué se escribe. La confluencia, por ejemplo, en $A L B$, de varias voces de tradición manierista, responde al deseo de subrayar lo continuidad esencial de la tradición amorosa occidental desde sus orígenes en la antigüedad clásica hasta ahora. ${ }^{6} \mathrm{Al}$ recorrer este texto, el lector tiene la ilusión de participar en un diálogo hipertrofiado, en una suerte de symposium sobre el amor, en que la situación de Hernando de Herrera, desamado por Doña Leonor, su "ecelsa Eliodora" y "luzero hermoso" se vuelve arquetípica de la de cualquier amante despechado. Este procedimiento, en un principio fragmentario, tiende luego a subrayar la comunidad de la voz poética, la solidaridad de la palabra y del destino humanos, el "uno" integrado al "vario," al mismo tiempo que expresa, paradójicamente, la irrisoria soledad del poeta condenado a una absurda empresa poética, pues vano es su intento de poetizar, de (re)crear la experiencia. Así, la poesía representa un antídoto contra la soledad -cada poeta comparte el destino de sus semejantes-a la vez que la enunciación de ésta. Lihn explica el uso que hace de esta modalidad de escritura como:

un doble e imperioso movimiento de solidaridad y desolidarización con los antiguos ocupantes de la poesía. Es la soledad de una palabra en una lengua que no le ofrece el amparo de una institución establecida de una vez y para siempre ... sino que, para el recién llegado, el rastro de otras experiencias de la palabra en el lenguaje, a las cuales se siente ligado en su soledad por una común anarquía (Lihn, Mensaje 1973, 552).

En su Curriculum, añade: "The ontological impossibility in Spanish America of being what one is, except in a relation of dependence or of independence with respect to Europe and especially to France, has something tragicomic about it" $(1978-79,14)$. Con desengaño es como baraja las "viejas cartas / marcadas" ( $M 25)$, aceptando filosóficamente la inescapabilidad del plagio literario:

Total, todas las cosas importantes son gratuitas ... incluso nuestras obras literarias frente a las cuales todo derecho de autor será, aunque bien recibido, insignificante ... Soy generoso, declino la responsabilidad de firmarlas a favor de uno de mis mejores discípulos ...

\footnotetext{
${ }^{6} \mathrm{En} A L B$, Lihn atribuye, en efecto, unos nombres pastoriles propios al Renacimiento y al Manierismo, tales "Cloris", "Filis", "Lisi" - recuérdense los poemas de Quevedo a Lisi-y no deja de evocar el tópico del locus horridus (58).

${ }^{7}$ El mismo título de la colección de Lihn está inspirado de unos versos de la Canción V de Herrera: El sacro rei de ríos que nuestros campos baña, al bello aparecer deste Luzero cubrió los vados fríos al pie de la montaña ...
} 
en cuanto a las criaturas humanas sólo en esta materia tan delicada el plagio resulta imposible razón por la cual aquí mi fiebre creadora declina y recupero mi temperatura normal puesto que yo también he transmitido la vida.

(PSI 77-78)

Si el hablante se autorretrata a veces cual un loro ridículo e insignificante, condenado a la repetición:

Un mundo de personas que yo ignoro como me reconozco en la ignorancia que ellas tienen de mícon su abundancia de igualdades me igualan: canto en coro.

Sus voces son las que repito: un loro inigualable por la resonancia con que pela su grito, la distancia así rasgada por un pico de oro.

(PSI 95)

deja adivinar, otras veces, la convicción de que, al recuperar una lengua ya usada y anticuada, ha contribuido a conservarle aliento vital:

Voz que de España vino, vuelve a España

vieja pero no muerta ni extenuada, por obra nuestra lengua deslenguada rápida como un corte de guadaña.

(PSI 102)

Particularmente ambigüo es, pues, para Lihn, el estatuto de la palabra en la que invierte tantas esperanzas de salvación al principio de su trayectoria poética. Recuérdense los versos que cierran la colección de La musiquilla de las pobres esferas, en los que apenas se imisce —en la penúltima línea — la presencia espectral de la soledad:

Porque escribí no estuve en casa del verdugo

ni me dejé llevar por el amor a Dios

ni acepté que los hombres fueran dioses

ni me hice desear como escribiente

ni la pobreza me pareció atroz

ni el poder una cosa deseable

ni me lavé ni me ensucié las manos

ni fueron vírgenes mis mejores amigas

ni tuve como amigo a un fariseo

ni a pesar de la cólera

quise desbaratar a mi enemigo. 
Pero escribí y me muero por mi cuenta, porque escribí porque escribl estoy vivo (M 83-84)

Sin embargo, el párrafo inicial de "El escupitajo en la escudilla" puede considerarse ya como el embrionario ars poética que ha de aclarar el conjunto de la producción lihniana:

Estoy lejos de querer significar algo. Escribo porque sí, no puedo dejar de hacerlo. Escritura de nadie y de nada, adiós, quiero decir hasta mañana a la misma hora, frente a esta espantosa máquina de escribir, poesía, será el acoplamiento carcelario entre tú y yo: seres hasta de cuyo sexo se puede dudar, me incrusto en mi rincón a esperar el deseo ( $M$ 73).

Aquí se edifican los pilares de su credo poético: la impotencia del escritor junto a la ineficacia e ilusoriedad de la palabra, debido al inexorable desajuste entre ésta y la experiencia. La empresa verbal llega pronto a destacarse en toda su dimensión exploratoria, como una instancia crítica y denunciadora por una parte, $y$, por otra, como una redención imposible. En sus conversaciones con Pedro Lastra, expresa su búsqueda del siguiente modo: "París, situación irregular me parece algo más que un libro de viaje ... la reflexión poética es uno de sus motivos, si no el motivo principal, de modo que el tránsito del viajero por un espacio irreconocible (pero que debe reconocer) es también el tránsito de la palabra por el papel" $(1980,63)$. Dicho "tránsito de la palabra por el papel”, dicha peregrinación lingüística mucho tiene que ver con el profundo deseo de colonización verbal sentido por el autor, quien admite que su poesía representa la "afirmación de una personalidad que quiere ser, en fin, la defensa de un sentido de la existencia sucesivamente contradicho o abortado por ese destino colonial que siempre ha parecido irreversible" (Padrón, Antología de poesía hispanoamericana, 1984, 22). Este impulso sería entonces un modo de anular o de compensar la colonización histórica antes padecida, a la vez que un intento de crear un nuevo juego de códigos propios para expresar el sentir del poeta hispanoamericano que acaba por percibirse como un viejo usuario de la palabra: “... la palabra me suena a cosa vieja y gastada, casi como un insulto. Con esta trompeta rota nada puede anunciarse, ningún juicio" (M77). Manifiestamente, topamos aquí con otra instancia de un encuentro incierto con la ratio difficilis:

Así todo problema insoluble, por cualquiera que sea, toma automáticamente el camino de la poesía que no lo resolverá, para empatar el tiempo (ED 36)

El estilo refleja más que nunca todas las incertidumbres del poeta:

... el estilo ... por cierto no es el hombre sino la suma de sus incertidumbres la invitación al ocio y a la desesperación y a la miseria 
Muy irónicamente, las piezas más manieristas de Belli son las que tratan del problema de la usura de la palabra. Así, con un tono reminiscente de los retruécanos escatológicos de las letrillas burlescas de Góngora, ${ }^{8}$ declama:

\author{
El soneto de forma recoleta \\ con sus catorce caras recortadas \\ no es un resumidero de cagadas \\ a menos que se escriba a la maleta. \\ Yo que soy por ejemplo pura jeta \\ -una lengua de víbora afamada- \\ dejo en el sonetear la mala hablada \\ de lado y me resigno a la receta. \\ Con elegante gesto, a la española \\ hablo de lo que no me importa un bledo: \\ cincel en mano dejo en paz al ego \\ y me tercio el soneto en banderola: \\ Lope de Vega, Góngora y Quevedo \\ como quien dice Pedro, Juan y Diego. \\ (PSI 92)
}

En estos versos, pues, si bien afirma conformarse a la receta carcelaria del soneto y así compartir las "glorias" de una retórica en la que Lope, Quevedo y Góngora se hicieron peritos, se entretiene, dialécticamente, en destituir a aquéllos del pedestal literario, por hallarse, al igual que él y el resto del vulgus pecum literario, sujetos a las mismas contingencias miserables: el espejismo de la palabra. En el soneto "Plumífero y vestido de payaso ..." desarrolla hasta el paroxismo la imagen del poeta con apariencia de loro grotesco, o mejor dicho, de albatros mitómano, orgulloso e impotente, víctima, como sus congéneres, de una horrorosa carencia verbal, en un mundo prosaico en que todos están condenados al uso comunitario del mismo patrimonio ró́do y ensuciado de la palabra poética:

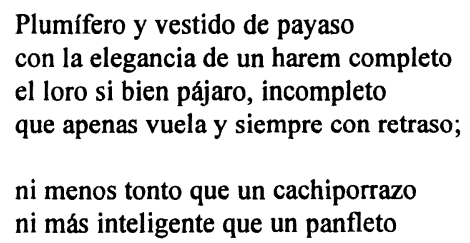

\footnotetext{
${ }^{8}$ Recuérdese en particular la letrilla XXVI:

Si en todo lo qu'hago

soy desgraciada

¿qué quiere qu'haga?

(Jammes, Letrillas, 1963, 186)
} 
de dos o tres palabras bien repleto y mucha labia el gran mariconazo. Monosapiente al modo de los locos que de una idea fija el mundo entero llenan torciendo el cuello sabiamente

para escarbarse en realidad los mocos u obligar a que tráiganle el sombrero; el loro, el loro, igual a tanta gente.

(PSI 98)

A pesar de sus empeños en conjurar esta maldición, en renovar la retórica antigua creando algo nuevo con lo viejo, ${ }^{9}$ no tarda en percatarse el poeta que, en cualquier lugar y sin que importen las posibles renovaciones retóricas efectuadas, la única realidad válida es la inanidad del signo lingüístico. La escritura, para Lihn, es un rito solitario e inútil, una yuxtaposición de "tropos, pavoneos de nada" ( $A L B$ 31): "Palabras que se desplazan continuamente incurriendo en todas las discontinuidades, subiendo o bajando de un nivel a otro, abarcando varios espacios a la vez con las consiguientes dificultades para avanzar, razonablemente, en alguna dirección" (PSI 75). Es un ejercicio intelectual por el que el poeta logra tan sólo penetrar un espacio ilimitado de vacío y de ausencia, un signo mallarmeano de "inanidad sonora" que oscila entre "una mudez inicial y final" ( $A A 13)$ :

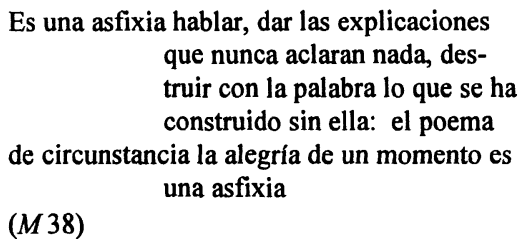

en fin, es una configuración que concretiza y anula:

En el [soneto] ${ }^{10}$ que yo escribí se hace uso de la palabra como el momento de desaparición del objeto, como el instrumento que da cuenta de su propia inanidad. Quise hablar en ese soneto sobre la impotencia de una operación en círculo vicioso que consistía en postular una presencia con los medios mismos que consuman su desaparición (Lastra 1980, 72).

Con una tragicidad contenido, se insurge contra la falacia del lenguaje denotativo:

Quienes insisten en llamar a las cosas por sus nombres

como si fueran claras y sencillas

las llenan simplemente de nuevos ornamentos.

No las expresan, giran el torno al diccionario,

inutilizan más y más el lenguaje,

\footnotetext{
${ }^{9}$ Véase el poema ya citado "Voz que de España vino, vuelve a España ..." (PSI 102).

10 "Qué sería de mí sin mis palabras" (PSI 114).
} 
las llaman por sus nombres y ellas responden por sus nombres pero se nos desnudan en los parajes oscuros.

(AA 16)

Se rebela contra la "musiquilla de las pobres esferas", que por su condición "sublunar" en términos bellianos - no puede acarrear más que trivialidad, carencia, horizontalidad y frustración cognoscitiva:

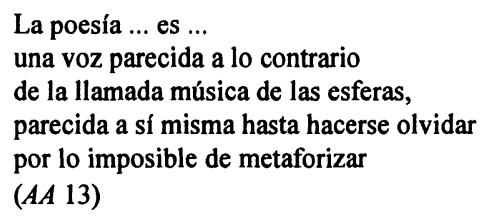

Últimamente, la palabra/espejismo se vuelve muda:

Y yo también dispongo de ese mismo artefacto que llaman el soneto para el uso discreto e indiscreto de quevedear sorteando en el abismo

de unas cuantas palabras, el mutismo de las cosas que entrampo en dos cuartetos y bajo doble llave en dos tercetos creo encerrar cazando un espejismo. (PSI 108)

Y las flácidas curvas verbales pasan de la atonía a la afasia permanente:
El verbo en cambio padece de una afasia permanente
es el mismo animal de hace cincuenta mil años
habiendo perdido por el camino cada una de sus formas.

(PSI 125)

Este mutismo desgarrador de la palabra llega a ser un doloroso grito sin voz, ${ }^{11}$ es decir un silencio cuyo espacio se organiza cual un gigantesco neumático recargado de significación. Lihn describe lo no dicho del modo siguiente: "La página en blanco por falta de espacio. Una asfixia que sólo permite respirar" (PSI 56).

El poeta se siente disminuido, como tal, por la mudez y la sordera:

\footnotetext{
"Maurice Blanchot califica esa prolepsia de "cri sans voix" $(1980,86)$.
} 
Yo le dije al autor de estos sonetos que soy una camisa de once varas gato de siete vidas y dos caras nada que ver con rimas y cuartetos.

Informal, mis secretos son secretos y no palabras ni palabras raras de éstas que cuestan poco y son tan caras a un roedor de oscuros mamotretos.

Pero el tal, sordo y mudo, me escribía con el hueco orejero de una mano pegado al rastro de una borradura

sobre el desierto del papel que hervía de mi cólera suya: andar en vano detrás del propio ser sin su escritura. (PSI 101)

No es más que un "escribiente" que se desgrana "bajo el peso del mundo" ( $M 75)$, en una labor que compara a la de las hormigas:

$$
\begin{gathered}
\text {... estamos condenados a escribir, } \\
\text { y a dolernos del ocio que conlleva este paseo } \\
\text { de hormigas } \\
\text { esta cosa de nada y para nada tan fatigosa } \\
\text { como el álgebra } \\
\text { o el amor frío pero lleno de violencia que se } \\
\text { practica en los puertos. }
\end{gathered}
$$

o que asimila a la de la oruga:

La oruga es una trabajadora infatigable, mata con su apetito sin boca algunos centenares de hojas

No deja más que huecos a su paso tal como lo pinta esta tarjeta postal.

(AA 29)

Escribir, para él, es desangrarse y sufrir una "anemia perniciosa" ( $A L B$ 85). Por eso se aprehende tal "un fantasma de rostro enloquecido / por la autotortura" (PSI 105).

Nunca se halla capaz de vencer la ansiedad infundida por la incertidumbre; así, su último libro, Pena de extrañamiento, concluye: "Estas líneas fueron escritas / con el canto de la goma de borrar" (57). Ni puede asumir tampoco su radical extranjerismo frente a la palabra. Sugerido primero por su condición real de extranjero en París, este tema cobra una dimensión obviamente alegórica en el resto de la obra: 
Vámonos vieja, vámonos a España

del exilio pasemos al exilio,

pero quizá de allí venga el auxilio, de nuestra propia lengua ...

Quienquiera oírnos, voz, y tenga oídos

pero para otra lengua y no la mía

ni la tuya, oirá sólo rüidos;

(PSI 103)

Así, está irremediablemente condenado a:

La tristeza de no poseer este idioma.

La alegría que sienten las palabras al coin-

cidir con su lengua,

ese despliegue de la voz como la cola de un

pavo real

después de extrañar todas sus plumas

(PSI 51)

En última instancia, las palabras llegan a simbolizar su inexorable "impotencia" verbal.

... yo en pie de qué,

en pie de poesía, en pie de nada ...

robo a la angustia horas de mi razón,

muriéndome

en el trabajo estéril del poeta,

en su impotencia laboriosa.

Sin mujer, con espanto,

laborioso.

(M 58)

Nótese aquí cómo, al igual que para Góngora y Belli, el acto poético, "el coitus interruptus de la escritura" (PSI 59), es asimilado al acto o al no acto eróticos:

Qué sería de mí sin mis palabras, sin mis pequeños signos de impotencia, yo a quien ni tan siquiera la impaciencia de una espera es posible. Mientras labras

tu ausencia aquí, a mi lado, sordamente mudo a lo menos yo no estoy: te escribo $y$ en el morir de la palabra arribo al pasivo delirio en que demente

voy llenando este hueco que me haces en carne propia con la tuya, el cuerpo de una escritura que se te parece 
y no se te parece, escrita yaces hecha de nada en un cuaderno muerto en el que mi palabra desfallece.

(PSI 114)

En este respecto, el proceso de la escritura simula la dinámica de ruptura, de desunión y de desencuentro del que es objeto el hablante en el plano amoroso. ${ }^{12}$

Poesía deseante o deseo poetizado ambos reflejan una obsesión por el no cumplimiento y la desconexión que pueblan la esfera (des)amorosa del sujeto poético cuya imaginación engendra una serie de situaciones paliativas, entre las cuales se destaca la siguiente:

Yo soy la Virgen y tú el Ángel de la Anunciación

- viene a decirme que voy a concebirte-

y el Espíritu Santo es la Literatura

no se sabe si usando de puertas o ventanas

entras a mi interior un misterio gozoso

para ser concebido en mí, la Virgen

no el poeta maldito

ni el sabio ni el ilota: la mente virginal

la mente vaginal

y el bolígrafo intacto: en un principio era el falo

$(A L B$ 45)

En un espacio resueltamente desprovisto de trascendencia, ${ }^{13}$ ni la mujer, con su promesa virtual de amor y de unicidad, puede colmar las aspiraciones del hablante: éste se halla condenado a cumplir, abandonado de todos, su largo naufragio solitario. Venus no es lucero de este mundo, pues, y la mujer que cruza su camino no es más que una "fulana" cualquiera, prosaica, que ni le tiende siquiera una mano soliviantadora:
No era siquiera una mujer fatal
bella, sí, pero espuma del oleaje
un simulacro de la Diosa ausente
$\mathrm{Ni}$ de pie sobre el mar: en la bañera
ni espuma: algo de carne, algo de hueso ...
ni tuvo al mar por mítico escenario ...

\footnotetext{
${ }^{12}$ Recuérdense aquí las palabras citadas anteriormente en este estudio: "poesía, será el acoplamiento carcelario entre tú y yo: seres hasta de cuyo sexo se puede dudar, me incrusto en mi rincón a esperar el deseo" (M73).

${ }^{13}$ Recuérdense los versos siguientes:

El cura, si lo hubiera, practica la absolución ante un espejo roto que multiplica su cara los guardianes del Orden establecido, esperan que alguna vez ese caos nos sea desfavorable. (PSI 123)
} 
En la ciudad más fea de la tierra se hizo humo a la hora de los quiubos Era fulana, y eso, simplemente y yo, el imbécil que escribió este libro.

(ALB 62)

Es muy significativo que el fresco pintado como trasfondo a las andanzas del sujeto lihniano esté poblado por una multitud de pobres diablos malamados y condenados a cumplir, en la más angustiosa soledad, unas viles funciones fisiológicas: en París, situación irregular, por ejemplo, desfilan sin parar travestistas, homosexuales y prostitutas. Parece que el amor mismo no es más que una falaciosa perspectiva de unión de dos irreductibles diferencias, una promesa ilusoria de escapar de la soledad; así, el hablante confiesa: "mi soledad babea tango a tango / el repertorio de las que se fueron" ( $M 16)$, y, amargamente, observa la inadecuación del vocablo "nosotros", "esta palabra llena de artificio / que siempre vuelve a significar / tú y yo" (M 52). Amor y soledad llegan a formar, como si matrimonio y el aburrimiento, "una pareja metafísica" ( $A A 27)$, desde el comienzo de los tiempos. A este respecto, Al bello aparecer de este lucero es una suerte de elegía a todos los amores fallecidos, "muertos" por no consumados, de la tradición estética occidental - trátese de la Lisi de Quevedo o de la Leonor de Herrera - una elegía, en fin, al lucero despiadado y ausente:

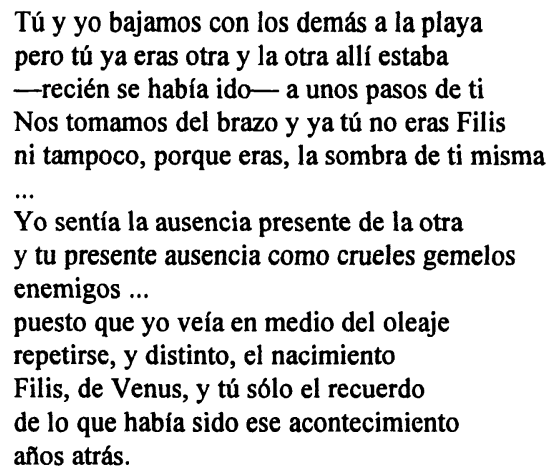

(ALB 18)

El amor, según el hablante, no deja de ser una palabra ( $A L B 59)$, y por lo tanto un concepto tan insignificante e inane como el signo que lo representa. En consecuencia, este signo debería ser borrado del vocabulario humano, y sustituido por una serie de vocablos de determinativos negativos o privativos, pues las mujeres sólo tienen, para el hablante, la "tarea / de privarnos del ser en la existencia” (PSI 109), de decepcionar, ${ }_{14}^{14}$ y de huir: "¿Poco importa que nuestros dedos entrelazados sean / los dos juegos de cuchillos?" ( $A L B$ 14).

\footnotetext{
${ }^{14}$ Véase la serie de poemas titulados "Decepciones" (ALB 72-73).
} 
El yo lamenta obsesivamente esa constante "identidad del corazón y de una bala imaginaria" ( $A L B$ 16), la inevitabilidad del desamor -del "amor y desamor enamorados" ( $A L B$ 33) - y del desencuentro - “... encuentros y desencuentros ¿en qué se diferencian?" $(A L B 20)$ - mientras predice y proyecta su destino trágico:

Graves inconvenientes se han constelado en el bello momento de tu aparición Me costarás, lucero, un ojo de la cara ( $A L B$ 54)

En efecto, el amante despechado, ese lastimoso Minotauro ( $A L B$ 84), se desmorona y desenfrena su indignación con el mismo patetismo que Polifemo:

Me cogoteaste el corazón, vampira y lo golpeo ahora con un combo para darle otra forma que la tuya.

o ¿no seguiste en eso por horror al vacío que soy, verdad, paloma? ( $A L B$ 21)

La carencia de amor significa para el hablante su propia carencia y su desaparición virtual de la escena vital, pues el deseo de ser amado refleja, a un nivel distinto, el ansia primordial de ser reconocido por el otro: ${ }^{15}$

Qué ausencia, querida, ocupé en mi presencia desfasado, en realidad, de la trama de la que tú eras la figura central y la gran tapicera a la vez en el sitial de honor desalentada pero no vencida por la impotencia real de incorporarme al tapiz ( $A L B$ 37)

De modo que la ausencia de la mujer amada acarrea consigo una variedad de desórdenes sicológicos en el sujeto, cuyo proceso de formación síquica aparece fragmentarizado, abortado y, últimamente, no cumplido.

Como el lenguaje que le configura, el hablante cobra de repente unos contornos evanescentes, atomizados e inanes:

Tú y yo no somos más que palabras

Nuestros nombres no le dicen nada a nadie identidad ilusoria de cada cual ... (ALB 66) no se trata de escepticismo sino de hechos las palabras como siempre están de más ante ellos.

\footnotetext{
${ }^{15}$ Nos valemos aquí, obviamente, de una premisa lacaniana.
} 

Nos hemos desdoblado en estas absurdas figuras o ellas se han desdoblado en nosotros, para el caso es lo mismo.

(PSI 124)

Y no tarda en operarse un colapso de la identidad por el cual el yo deja de experimentar la extensión de sus propios límites. Primero, se desdobla el sujeto:

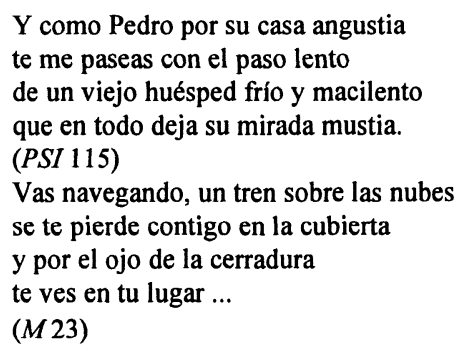

Luego, su habla: "Hasta los palabras tienen que desdoblarse / esralbodsed" (PSI 55). De repente, se pulveriza, no llega a percibir más que "las piezas del mosaico / deshecho de [su] cara" (M 22), y pierde la noción de su individualidad: "Hoy me siento el extranjero, descifro / otra mano en la palma de la mía" (M24). Su vísión se altera, acarreando así una disolución del tiempo y del espacio fenomenológicos:
Como si en un lugar nos encontráramos en distintos sitios al mismo tiempo
Imágenes superpuestas que a veces coin- ciden y otras no

(PSI 41)

Se multiplican las metamorfosis, por las que el hablante aparece ora bajo los rasgos de la amada:

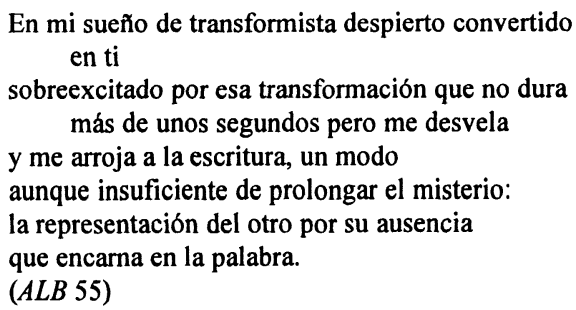

ora cual página de libro: 
También el cuerpo se descompagina porque lo hojeen distrafdamente Soy un imbroglio de maltratado papel entre las manos de una lectora poco atenta un magazine en una sala de espera que irá a parar en unos días más a la bolsa negra de polietileno Antes de que esto ocurra, lee en mí el último capítulo de nuestra historia en común para que sepas.

(ALB 57)

o cual pez, a punto de ahogarse:

Un pez algo más chico que una botella con agua en forma de pez donde está en trance de ahogarse pues no puede ponerse de cabeza y su boca coincide con el gollete. $(A L B 75)^{16}$

La pesadilla, en que ve atomizarse totalmente los límites entre su dominio privado y la esfera pública, ${ }^{17}$ pronto se transforma en realidad oprimente y ubicua de la que la ciudad es el marco privilegiado:

Un tubo de azulejos que hace caracolear al cuerpo comprimido

por la escalera en que el cuerpo pierde su

(PSI 56) espacio

Deténgase el mundo entero quiero verificar mi dirección

sin tenerlos a todos pisándome los talones medio millón de accidentes de tráfico.

Así los quiero ver convertidos por unos instantes en medio millón de estatuas

un enorme friso subterráneo

(PSI 40-41)

Una realidad que ha de culminar en el poema "Locus horridus", al hallarse traspasado el cuerpo del sujeto por unos médicos inquisidores: "cinco o seis médicos entran y salen de

${ }^{16}$ Nótese de paso la afinidad entre estos versos y los siguientes, sacados del soneto XXI de Herrera: Por esso no os ofenda mi flaqueza

bella Estrella d'Amor; que mi tormento

no cabe bien en vaso tan estrecho.

${ }^{17}$ En alguna instancia, el yo poético afirma: “... soy el público y el autor, los actores y el escenario / deshaciéndose el todo sobre mi cabeza" (ALB 53). 
mi cuerpo / sin obtener informaciones precisas / Y no puedo irme ni quedarme de aquí" (ALB 59).

Con una inaudita anarquía, se realiza, en la relación (des)amorosa, una fragmentación corporal violenta, en que los órganos están por completo trastocados:

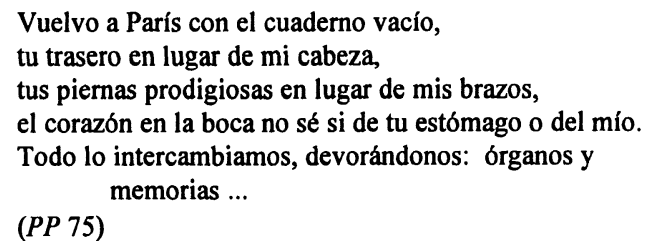

Como para Belli, se manifiesta, en fin, la obsesión esquizofrénica de la máquina deseante, de modo que el yo puede imaginarse a veces íntimamente conectado a una máquina, en este caso, se trata de la maquinaria telefónica:

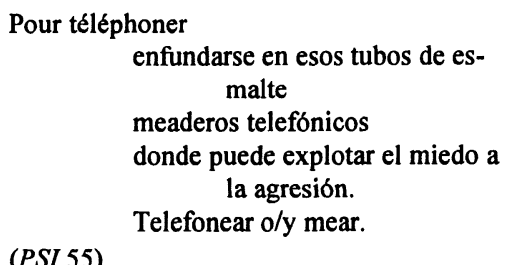

Como es lógico, parecido dislocamiento síquico no deja de afectar la cosmovisión del hablante poético. La inexistencia de un hilo narrativo "coherente", el salto continuo entre un pasado y un futuro que no son más que dos modalidades de un presente absoluto, ilustra la destrucción del tiempo y del espacio fenomenológicos, sustituidos por el reino de la "no experiencia", del "afenómeno", ${ }^{18} \mathrm{y}$ de la incertidumbre. Tanto el reconocimiento de la indeterminación del fenómeno y de la influencia del observador, como el interés por explorar, no el fenómeno en sí, sino el conocimiento que se tiene de él, son preocupaciones esenciales de la poética de Lihn. ${ }^{19}$

La noción absoluta del Tiempo, por ejemplo, es un concepto ilusorio y vacío, tan sólo creado por el sujeto. Así, Carmen Foxley nota cómo "... la combinación sucesiva de los fragmentos no depende de algún tipo de temporalidad "cronológica' del 'diario de viaje"' y sugiere la noción de "contagio" $(1977,26)$. En efecto, la organización temporal se debe, para Lihn, a un procedimiento asociativo cuya dinámica, como en el de la metaforización, reside en un encadenamiento metonímico.

\footnotetext{
${ }^{18}$ Términos prestados de M. Blanchot (1980), quien habla repetidamente de "hors expérience" y de "hors phénomène".

${ }^{19}$ Nótese cómo estas tres premisas son las mismas que rigen las empresas de la física cuántica.
} 
Por otra parte, la concepción filosófica del tiempo halla su justificación teórica en un razonamiento algo sofista. Las premisas del sofismo son las siguientes; en primer término, el tiempo es una configuración de la memoria, la cual, a su vez, viene engendrada por la palabra; en segundo término, la palabra es inane; en tercer término, el tiempo es inane e inmaterial; por lo tanto, el tiempo también queda inane y abolido:

$\ldots$ años

... que a la larga nadie llegará a recordar.

El mañana no existe.

Pasado y futuro se han invertido, el mañana

será alguna de las otras escenas agolpadas en mi memoria.

(ED 13)

Así es como el sujeto puede exclamar: "Ya no estoy aquí. Me fui en dos o tres días más" (PSI 69), y reducirlo todo a un inmenso presente:

... La que esté allí

es sólo una visión a la espera de un taxi de hace diez o

quince años

sin haber envejecido porque en ese país

no se vive ni se muere

( $A L B$ 20)

Según el mismo Lihn, "El tiempo actual reitera el pasado, lo presentifica. Se trata de un tiempo, pues, que pasa y no pasa, que se extiende más y más hacia ese pasado a medida que avanza hacia el futuro" (Lastra 1980, 34). Así, en su poema "Laberintos", menciona “... una historia que fue [y] llega a su fin / porque está en el pasado su futuro" $(A L B 23){ }^{20}$ Ese presente, con su extensión infinita, se hace tan agobiante e insondeable como el mar - "mar y tiempo se unen por la partícula de" $(A L B, 67)$ - y llega a invalidar cualquier noción de carpe diem, puesto que el único fluir temporal existente es el regulado por los recuerdos:

Los aparentes días de verano que por la superficie del mar fluyen y que como las nubes se diluyen cuando no sopla el viento, en lo lejano

${ }^{20}$ Octavio Paz comenta el mismo fenómeno en el conjunto de la poesía posvanguardista en los términos siguientes:

La visión del ahora como centro de convergencia de los tiempos, originalmente visión de poetas, se ha transformado en una creencia subyacente en las actitudes e ideas de la mayoría de nuestros contemporáneos. El presente se ha vuelto el valor central de la tríada temporal. La relación entre los tres tiempos ha cambiado, pero este cambio no implica la desaparición del pasado o la del futuro. Al contrario, cobran mayor realidad: ambos se vuelven dimensiones del presente, ambos son presencias y están presentes en el ahora .... El fin de la modernidad, el ocaso del futuro, se manifiesta en el arte y en la poesía como una aceleración que disuelve tanto la noción de futuro como la de cambio. El futuro se convierte instantáneamente en pasado; los cambios son tan rápidos que producen la sensación de inmovilidad (1974, 204-205). 


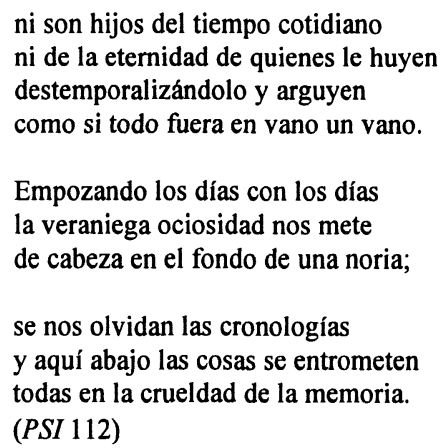

Últimamente, todo fenómeno queda, para Lihn, configurado por la memoria, madre genitora del otro/s, o del desencuentro:

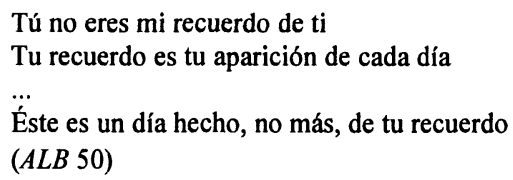

una memoria que se halla a la raíz de todas las proyecciones espaciales percibidas por el hablante poético:

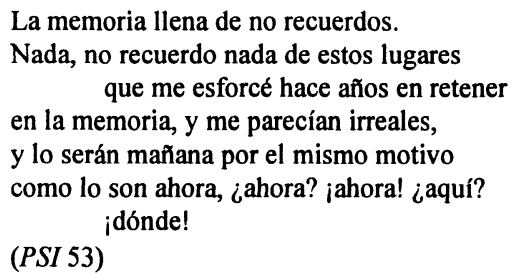

No obstante, la memoria, que "todo lo sabe en materia de sombras" (PSI 83), no produce más que un espejismo de realidad _ _... la realidad es un espejo de feria" (PE 51)- dejando al hablante, una vez más, frustrado y sentenciado a sólo poder asir una ínfima partícula de ella, y aun así, una partícula fugaz e incierta: "Es un pez o algo así lo que esperamos pescar / algo de vida, rápido, que se confunde con la sombra / y no la sombra misma ni el Leviathan entero" ( $A A$ 17).

Ambos, Góngora y Lihn, ven en su escritura poética el modo de expresión más adecuado para procesar la discontinuidad inherente al proceso cognoscitivo. Más aun, la página poética llega a representar la misma disolución del fenómeno: “... se hace uso de la palabra como el momento de la desaparición del objeto, como el instrumento que da cuenta de su propia inanidad ... [es como] postular una presencia con los medios mismos que consuman su desaparición" (Lastra 1980, 72). 
Para Lihn, tanto la retracción verbal, el no decir, ese conjunto de criptas verbales significantes, como la expansión vertiginosa del signo lingüístico, vienen a simbolizar las dos instancias de una misma realidad el doloroso planteamiento de la duda como principio noseológico:

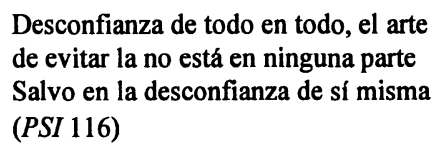

A este respecto, la atonía verbal y su correlato inexorable, la ausencia, anuncian, en la retórica de Lihn, la realización de los primeros pasos hacia lo que Maurice Blanchot llama "la escritura del desastre" (1980). ${ }^{21}$

${ }^{21}$ Véase el título de su libro: $L$ 'Écriture du désastre. 